\title{
General education, vocational education and skill mismatches: short-run versus long-run effects
}

\author{
By Dieter Verhaest ${ }^{a}$, Jeroen Lavrijsen ${ }^{b}$, Walter Van Trier ${ }^{c}$, Ides Nicaise ${ }^{d}$, and Eddy \\ Omey
}

a KU Leuven, Faculty of Economics and Business, Campus Brussels, ECON Research Group and Leuven Economics of Education Research (LEER); Warmoesberg 26, B1000 Brussels, Belgium; e-mail:

Dieter.Verhaest@kuleuven.be

b KU Leuven, Research Institute for Work and Society (HIVA); e-mail: jeroen.lavrijsen@kuleuven.be c Ghent University, Faculty of Economics and Business Administration, Department of Economics; e-mail: Walter.VanTrier@UGent.be

d KU Leuven, Research Institute for Work and Society (HIVA) and Department of Educational Sciences; e-mail: ides.nicaise@kuleuven.be

e Ghent University, Faculty of Economics and Business Administration, Department of Economics; e-mail: Eddy.Omey@UGent.be

Forthcoming in Oxford Economic Papers

Abstract

Earlier research showed that obtaining a vocational instead of a general qualification has contrasting effects on employment and earnings over the life course. Relying on two international datasets (ESJS and PIAAC) and focussing on upper-secondary and post-secondary non-tertiary qualifications, we find similar contrasting effects in terms of educational and skill mismatches. While vocationally educated individuals are less likely to face mismatches at the start of their careers, this advantage gradually fades out over time. This pattern is not only found for overall mismatches, but also for mismatches in terms of several more detailed types of skills. We also find more favourable effects in terms of avoided mismatches for vocational programmes that combine a specific focus with workplace learning, while programmes that combine a less-specific focus with workplace learning seem to be less effective.

JEL codes: 126, J24

Citation: Verhaest, D., Lavrijsen, J., Van Trier, W., Nicaise, I., \& Omey, E. (2018). General education, vocational education and skill mismatches: short-run versus long-run effects. Oxford Economic Papers, forthcoming. 


\section{Background}

A major question concerning the effectiveness of education in promoting labour market opportunities is whether programmes should be vocationally or generally oriented (Ryan, 2001; Hayward, 2004). Within Europe, vocational systems have for a long time been considered to be relatively more successful. Indeed, research indicates that vocational systems are usually associated with a more smooth school-to-work transition process and with reduced levels of youth unemployment (Müller and Gangl, 2003). American scholars, however, have praised the merits of a more general educational system (Goldin, 2001; Krueger and Kumar, 2004). In times of changing labour market needs, resulting from rapid technological progress and globalization, employees need to be adaptable. This is likely to be relatively more problematic for vocationally educated workers, whose skills are more strongly tied to a specific context. As Hanushek et al. (2017) argue policy makers may thus encounter a trade-off, with general programmes being less effective in promoting short-run labour market success but more effective in the long run. Hanushek et al. provided empirical support for their thesis by showing that generally educated individuals compensate a lower employment rate at younger ages with a higher employment rate at later ages. A number of other recent contributions confirmed this conclusion and also found some evidence on a similar trade-off in terms of earnings (Stenberg and Westerlund, 2015; Forster et al., 2016; Hampf and Woessman, 2017; Lavrijsen and Nicaise, 2017). Brunello and Rocco (2017) conversely found more mixed evidence for such a trade-off in the case of academic versus vocational education in Britain.

Rather than focusing on employment rates and earnings, we investigate in this article an alternative trade-off in terms of educational and skill mismatches. At the start of the career, generally educated workers may be more likely to lack the vocational skills that are needed to carry out their jobs. Hence, they may be more likely to start working at lower-level jobs (cf. Sicherman and Galor, 1990), thus being more likely to be overqualified and also being more likely to face a surplus of more general skills. However, as their career advances, their strong basis of foundation and learning skills is likely to be helpful in acquiring the necessary vocational and specific skills by means of additional informal training and workplace learning. Vocationally educated individuals, on the other hand, are likely to be productive almost immediately after labour market entry and, hence, will realize a relatively good match with all their skills and qualifications. Over time, however, as labour market needs change, these individuals risk building up surpluses with respect to skills that become obsolete and shortages with respect to newly required skills. Due to lower levels of general and foundation skills, 
these shortages may not easily be filled by means of additional workplace training and learning by doing. Hence, they risk being downgraded to lower-level jobs in the same organisation or becoming unemployed and having to take jobs as overqualified workers in other organisations.

Several studies have, indeed, found that vocationally educated individuals are more likely to realize a match between acquired and required qualifications in their first jobs (e.g. Arum and Shavit, 1995; Heijke et al., 2003; Giret, 2011; Levels, van der Velden and Di Stasio, 2014). Moreover, some studies found that vocationally educated individuals who are nevertheless overqualified in their first job are more likely to be persistently overqualified (Verhaest and van der Velden, 2013; Verhaest et al., 2015). Finally, some research also indicated that these overqualified vocationally educated individuals acquire less additional skills than overqualified generally educated individuals (Verhaest and Omey, 2013). While all of this is supportive for a trade-off between the short-run and long-run effects on educational mismatches, a recent contribution by Verhaest and Baert (2017) did not find any evidence on differences between graduates with and without curriculum-based workplacement experience in their likelihood to be overeducated in the first job, nor in the likelihood to remain overeducated.

We contribute in three main ways to this discussion on the short-run and long-run effects of vocational versus general education on mismatches. First, given that the focus of the aforementioned studies was on the first years of the career, it remains to be investigated whether generally educated individuals are truly less likely to be overqualified in the longer run. In line with Hanushek et al. (2017), we investigate whether the relative effects of vocational versus general education change over the career. Secondly, we measure mismatches not only in terms of qualifications (i.e. educational mismatch) but also in terms of skills (i.e. skill mismatch) (cf. Allen and Van der Velden, 2001; Green and McIntosh, 2007). As explained, depending on the type of skill considered, the impact on skill mismatches may differ from the impact on educational mismatches. Finally, as opposed to the aforementioned studies, we evaluate the extent to which programmes are vocationally oriented along two different dimensions: the extent to which they have a more specific focus and the extent to which they include workplace-based learning. While there is substantial variation along these two dimensions across different programmes, it yet remains to be investigated which of these two characteristics of vocational education is the most important in explaining the aforementioned trade-off.

A specific focus on educational and skill mismatches in the context of the effects of vocational and general education is interesting for two main reasons. First of all, overeducated and overskilled workers are consistently 
found to be penalized in terms of earnings (Hartog, 2000; Rubb, 2003; McGuinness, 2006; Levels, van der Velden and Allen, 2014) and there is also some evidence that these mismatches are associated with higher risks of losing one's job (McGuinness and Wooden, 2009), becoming unemployed (Sloane et al., 1999; Mavromaras et al., 2015) or retiring early (Bender and Heywood, 2017). Hence, our analysis may improve our understanding regarding the mechanisms underlying the aforementioned effects of vocational and general education on earnings and employment. Secondly, skill mismatches are also found to have a more direct negative effect on individual well-being. Apart from being associated with lower job satisfaction (Allen and van der Velden, 2001; Green and Zhu, 2010; Mavromaras et al., 2013), skill underutilisation seems to result in reduced life satisfaction, happiness and mental health (Bracke et al., 2013; Artés et al., 2014; Piper, 2015; Zhu and Chen, 2016). Our study is therefore complementary to studies focussing on other outcomes and should allow to make a more comprehensive assessment of the extent to which the relative effects of vocational versus general education on individual well-being change over the life course.

For our analysis, we primary rely on the European skills and jobs survey (ESJS) ${ }^{1}$ data. This dataset covers the full work force for a large set of countries. This allows comparing younger with older cohorts. A major advantage of the ESJS data is its detailed information on both educational and skill mismatches and on the type of vocational education. However, the data are less rich in terms of information on abilities and social background. Therefore, we complement the ESJS results with some additional analyses relying on the data of the Programme for the International Assessment of Adult Competencies (PIAAC). PIAAC contains detailed information on numeracy and literacy skills based on standardized assessment test procedures. This enables us to investigate, at least partly, to what extent the observed differences are driven by ability bias.

Because of data limitations and data comparability issues, we focus in this paper on medium educated individuals (with their highest qualification achieved on the secondary or post-secondary level). An interesting issue for future research could thus be the extent to which our results apply to tertiary education as well.

\footnotetext{
${ }^{1}$ European Centre for the Development of Vocational Training (Cedefop). Cedefop European skills and jobs survey (ESJS), Wave 1, Spring 2014 [computer file], 1st edition, Thessaloniki: Greece, retrieved from: http://www.cedefop.europa.eu/en/events-and-projects /projects/analysing-skill-mismatch on 16/2/2015. ESJS microdata are Cedefop copyright and are reproduced with the permission of Cedefop. Further information is available at Cedefop (2015).
} 
The paper is structured as follows. In the next section, we provide more information regarding the two datasets and our research methods. Next, we present the results relying on the two datasets. We end with a discussion and conclusions.

\section{Methodology}

\subsection{Data and sample selection}

The ESJS was commissioned by CEDEFOP with the aim of measuring the degree of skill mismatch and skill obsolescence across Europe. The ESIS was conducted in 2014 among 48,676 employees between 24 and 65 years old from the $28 \mathrm{EU}$ countries. The data were gathered both through online and telephone interviewing. To guarantee representativeness, quota sampling was used. More information on the survey and composition of the sample can be found in Cedefop (2015).

To assess the importance of selection on unobservables, we complement the ESJS results with a few analyses relying on PIAAC. The PIAAC survey was commissioned by the OECD to assess the numeracy, literacy and problem-solving skills of the adult population. The survey combined a computer aided personal interview with detailed assessment tests. We rely on the first wave of the survey, which was conducted in 22 OECD member countries and the Russian Federation. We do not include Canada, Estonia, the Russian Federation and Australia because of missing information on a number of key variables. More information on the survey can be found in the technical report (OECD, 2013).

For both datasets, we select respondents aged between 20 (24) and 65 years who had a job at the time of the survey. We exclude respondents who were born or earned their qualification outside the country of residence. Finally, we confine our analysis to the medium educated, which we consider to be those who reported an ISCED 3 or 4 qualification as the highest qualification achieved. To account for the complex sampling designs, all data are weighted using sampling weights and giving the same weight to each country (cf. Hampf and Woessman, 2017; Lavrijsen and Nicaise, 2017).2

Using international datasets allows us to identify the average effect of vocational education across different countries. However, as Hanushek et al. (2017) showed, this average may hide substantial differences in effects with dual system countries facing the most pronounced trade-off. Therefore, relying on ESJS, we also

\footnotetext{
${ }^{2}$ For a recent study on the importance of weighting when using international survey data on skills, see Jerrim et al. (2017).
} 
conduct some analyses for specific groups of countries. A first group of countries includes four traditional dual system countries (Austria, Denmark, Germany and Luxembourg). In a second group, we additionally include four Central and Eastern European countries with a dual system (Czech Republic, Hungary, Romania and Slovenia). For this categorisation, we rely on Kogan (2008). Finally, we consider a broader group of vocational countries that also includes those with a vocational share of at least 50 percent in upper secondary education for 2014 according to Eurostat (2016).

\subsection{Educational and skill mismatches}

The ESJS delivers detailed indicators on both educational and skill mismatches relying on self-assessments. For the measurement of educational mismatch, we rely on the following two survey questions: "What are the educational qualifications, if any, that someone actually needs to do your job today?" and "If someone was applying for your job today, what qualifications, if any, would they need to get the job?" This delivers two different measures of the level of required education for the job. Although measures relying on the required level to do the job are sometimes considered more appropriate (Dolton and Silles, 2003), both are frequently used in the literature. To measure the level of over- and undereducation, we compare this required level with the actual level of education obtained. One is overeducated according to definition one (two) in case the obtained level of education is above the level needed to do (get) the job. The degree of overeducation is measured as the difference between one's obtained level of education and the level of required education for those being overeducated and set to 0 otherwise. The level of undereducation is measured in a similar way.

Regarding overall skill mismatches, we rely on the following question in the ESJS: "Overall, how would you best describe your skills in relation to what is required to do your job?" The respondents could assign one of the following answers: (1) "My skills are higher than required by my job", (2) "My skills are matched to what is required by my job", and (3) "Some of my skills are lower than what is required by my job and need to be further developed". In addition, those providing answer (1) (respectively (3)) and thus being overskilled (underskilled) were asked: "To what extent would you say your skills are higher (lower) than required to do your job?" with answer categories ranging from 1 ("My skills are a little higher (lower) than required") to 5 ("My skills are a lot higher (lower) than required"). Combining the information on each of these questions delivers a variable measuring the degree of overskilling (underskilling) ranging from 0 (in the case of no overskilling (underskilling)) to 5 (severe overskilling (underskilling)). Along with the aforementioned questions, the survey also includes the 
following question: "Think about the level of skills needed to do your job as well as possible. How would you rate your own level of skills? Please answer on a scale of 0 to 100, where 0 means you need to develop all of your skills and 100 means you have all the skills you need." Rather than measuring over- and underskilling, this question measures the extent to which the individual is adequately skilled. To be consistent with the other indicators, we reverse the scale with higher values indicating higher levels of inadequate skilling.

While the aforementioned skill mismatch indicators pertain to overall skill levels, the ESJS also allows to assess mismatches in terms of so-called 'foundations skills' (numeracy, literacy and ICT) and mismatches in terms of the eight other, more detailed types of skills. For each of these skills, respondents each time got the question: "How would you best describe your skills in relation to what is required to do your job? Please use a scale of 0 to 10 where 0 means your level of skill is a lot lower than required, 5 means your level of skill is matched to what is required and 10 means your level of skill is a lot higher than required." ${ }^{3}$ To measure the degree of over- and underskilling in terms of each of these skills, these answers are recoded to a scale from 0 (no overskilling (underskilling)) to 5 (serious overskilling (underskilling)).

For PIAAC, we measure over- and undereducation by using the answers to the question "Talking about your current job: If applying today, what would be the usual qualifications, if any, that someone would need to get this type of job?" The level of overeducation is defined as the difference between the highest qualification achieved (which is ISCED 3 or ISCED 4 for all respondents in our sample) and the required qualification. In particular, this difference is set equal to 3 in case no formal qualification or only a qualification below ISCED 1 is required, equal to 2 if a qualification at level ISCED 1 is required, equal to 1 if a qualification at level ISCED 2 is required, and equal to 0 otherwise. Similarly, undereducation is set equal to 1 if a qualification at level ISCED 5 is required and equal to 2 if a qualification at level ISCED 6 is required, and 0 otherwise. PIAAC does not include a survey question that refers to the required qualification to do the job.

Our measures of overskilling in PIAAC are inspired by Allen et al. (2013) and start from the responses of the respondent to a set of 18 questions regarding the use of numeracy and literacy skills at work. Respondents

\footnotetext{
${ }^{3}$ Regarding the three foundation skills, these questions were preceded by another question regarding the highest level of skills required for doing the job (e.g., in the case of literacy skills: basic literacy versus advanced literacy). The skill mismatch question then referred to the relevant level of skills. For instance, in the case a respondent indicated advanced literacy skills were required, the skill mismatch question referred to the extent to which his/her advanced literacy skills were higher or lower than required.
} 
had to answer these questions on a scale ranging from 1 (never) to 5 (every day). The average of the responses to questions 1-6 is used to measure numeracy skill use and the average of questions 7-18 is used as a measure of literacy skill use. We standardize both measures of skill use and subtract them from the standardized numeracy, respectively literacy score of the respondent. ${ }^{4}$ While this newly generated variable $(k)$ delivers an indication of the degree of skill underutilisation, it does not allow to determine who exactly is overskilled and who is underskilled. Nonetheless, research relying on other data in general finds overskilling to be much more prominent than underskilling. ${ }^{5}$ Therefore, we assume that the cut-off value of $k$ to differentiate between overskilled and underskilled workers is below zero. By replacing negative values of $k$ by zero, we thus get a (censored) measure of the degree of overskilling. ${ }^{6}$ A major drawback of this approach to measuring overskilling is that it supposes a linear relationship between skill use and skill requirements. While this is a strong assumption, an alternative is to interpret these indicators as measuring skill use relative to one's own skill level (Allen et al., 2013). If so, results based on these indicators are still informative given that the correlation between skill use and requirements is unlikely to be non-positive. Nonetheless, the results relying on these indicators are to be taken as merely indicative.

\subsection{The orientation of the programme}

Most studies rely on institutionalized qualification frameworks to distinguish between general and vocational education. This approach has two main disadvantages. First, the labelling of qualifications as vocational or general depends on administrative decisions. These decisions are not necessarily based on a robust definition of what determines whether a programme is vocational or rather general. Given that qualification and educational systems differ across countries, this problem is reinforced when relying on cross-country data. Second, this categorisation does not take into account that the orientation of programmes may be assessed along two different dimensions: the specificity of the programme and the extent to which it relies on practicebased learning. Programmes that rely on practice-based learning are not necessarily specific in their focus. Similarly, programmes may well be specific in their focus while only relying on standard classroom instruction

\footnotetext{
${ }^{4}$ As Levels, van der Velden and Allen (2014), we rely on the first plausible value.

${ }^{5}$ For instance, in EU-SKILLS, 38.8\% (5.9\%) reported to be overskilled (underskilled).

${ }^{6}$ In Allen et al. (2013), cut-off points of 1.5 resp. -1.5 were applied to classify respondents in a trichotomous way as being overskilled, matched respectively underskilled. We opted not to apply such a dummy classification because it involves an unnecessary loss of detail.
} 
training.

The ESJS allows overcoming these two problems by relying on two survey questions. The first question measures whether the programme included workplace-based learning and is formulated as follows: "Did your study take place only within an educational institution (e.g. a school, college or university) or did it involve some learning in a workplace (e.g. through apprenticeships, internships, or other forms of work-based learning)?" The second question rather measures the specificity of the programme: "Overall, would you describe your highest qualification as a vocational qualification? Vocational means it is designed for acquiring knowledge, skills and competences closely linked to a particular job or trade." Combining the answers to these two questions allows differentiating between the following four types of programmes: (A) No workplace learning, not specific, (B) Workplace learning, not specific, (C) No workplace learning, specific, and (D) Workplace learning \& specific. We report results relying on one overall vocational programme category (including (B)-(D)) as well as results that differentiate along the aforementioned dimensions.

Unfortunately, this differentiation cannot be implemented within PIAAC. Hence, for the PIAAC analysis, we opt to classify educational programme according to the following standardized framework: national qualifications are classified as "vocational" when more than $25 \%$ of their content was oriented towards a specific class of occupations or trades, and as "general" otherwise. This classification is only available for the ISCED 3 and ISCED 4 levels. Hence our decision to confine our analysis to the medium educated.

\subsection{Model specification}

We investigate the impact of the orientation of the programme by means of a model having the following general form:

$Y_{i}=\beta_{1} V O C_{i}+\beta_{2} V O C_{i} * T I M E G_{i}+\beta_{3} T I M E G_{i}+\beta_{4} T I M E G_{i}^{2}+\mathrm{X}_{i} \beta_{5}+\varepsilon_{i}$

With $Y_{i}$ being a measure of mismatch for individual $i, V O C_{i}$ being a dummy or a series of dummies measuring the vocational orientation of the programme of one's highest education or training, TIMEG $i$ being time since graduation, $X_{i}$ being a vector of control variables and $\varepsilon_{i}$ being a residual term. While our specification is largely in line with other contributions on this subject, most previous studies rather examine whether the effects of education differ by age instead of time since graduation (e.g. Hanushek et al., 2017). Given that there is some variation in the age at which individuals obtain their highest qualification, we consider time elapsed since 
graduation to be more appropriate.

Our main hypothesis relates to parameter $\beta_{2}$, which is expected to be positive. This would imply that mismatches decline (increase) relatively less (more) rapidly over one's career for vocationally educated individuals. This hypothesis is based on the presumed higher adaptability of individuals with a general qualification and the presumed higher rates of skill obsolescence among individuals with a vocational qualification. Higher levels of adaptability or skill obsolescence may affect skill mismatch directly as well as indirectly, through their impact on unemployment and participation in further informal training. For instance, generally educated individuals may gradually reduce their mismatches if additional informal training is relatively more effective for them. Unfortunately, our data do not allow to incorporate these indirect influences. Our model should therefore be interpreted as a reduced form model in which the interaction effect between vocational education and time elapsed since graduation, amongst others, results from differential dynamics in experience and training participation.

We measure time since graduation by the difference between the current age of the respondent and the self-reported age of completion of one's highest level of education or training. In PIAAC, these data are missing for Austria, Germany and the US; for these countries we approximate the time since graduation by the difference between current age (reported for these countries in 5-year-bands only; we used the midpoints of these bands) and an expected average age of graduation equal to 18.5. This value approaches the graduation ages reported for ISCED3-qualifications in these countries (OECD, 2014). The control variables that are added are, for both analyses, gender, country dummies, age and education measured by ISCED.

Access to educational programmes is unlikely to be random: different programmes cater for different parts of the ability distribution. The ideal solution to this problem would be to include some indicator of "preenrolment" or "innate" ability. However, this would require longitudinal datasets combining ability scores measured at a young age with labour market outcomes observed later in life. In this paper, we adopt the approach proposed by Hanushek et al. (2017) and Hampf and Woessmann (2017). First of all, as they argue, this selectivity is an issue in particular for the estimation of parameter $\beta_{1}$. Conversely, parameter $\beta_{2}$ can be interpreted within a difference-in-difference framework. A crucial assumption to identify the effect of the educational programme on the changes in skill mismatches over the career is that the relative selectivity of vocational and general programmes does not change over time. Relying on the International Adult Literacy 
Survey, Hanushek et al. (2017) found that the difference in literacy scores between generally and vocationally educated individuals is relatively stable over the life course. Also, based on PIAAC, we find test score differences to be relatively stable across age cohorts (see online Appendix 1 in the Supplementary material). Secondly, relying on PIAAC, we also estimate specifications with social background variables (parental education and the number of books at home) and measured skills as control variables. ${ }^{7}$ The inclusion of measured skills is expected to affect the estimation in two ways. It removes (part of) the selectivity due to differences in intake, but it may also remove (part of) the general-cognitive effect of general education itself.

Another bias may stem from relative changes in the curricula over time. To the extent that these reforms may be diverse, they should not affect skill differences between generally and vocationally educated individuals systematically in the same direction for all countries. Nonetheless, some bias cannot be excluded. As outlined by Kogan (2008), many former communist countries have moved from a vocational dual system to a system in which school-based training plays a more prominent role. Moreover, Western countries like The Netherlands and Sweden have also implemented significant reforms in the past (Hampf and Woessman, 2017). We therefore also carry out some analyses on a sample that excludes these countries.

\section{Results}

\subsection{Overall educational and skill mismatches (ESJS)}

In table 1, we present our estimation results regarding overall educational and skill mismatches relying on the ESJS. Given the censored nature of our outcome variables, we apply a Tobit specification. We report results on three different specifications. In a first specification $(A)$, we only include a dummy for vocational programmes (along with control variables). Specification (B) adds an interaction term with years since graduation. Finally, in specification (C), we also differentiate between the three types of vocational programmes.

The results relating to educational and skill surpluses (Column $(A)-(C)$ ) are broadly in line with our hypothesis. Vocational programmes are found to be associated with lower levels of both overeducation and overskilling at the start of the career (Specification (B)). Further, as expected, we also find some evidence that

\footnotetext{
${ }^{7}$ When a measure of educational mismatch is the dependent variable, we report results using numeracy skills as the control variable; results controlling for literacy skills are equivalent. When numeracy resp. literacy overskilling is the dependent variable, we use the corresponding skill as the control.
} 
these effects diminish with years since graduation. However, the size and significance of these interaction effects differ across the vocational programmes (Specification (C)). Regarding overeducation, particularly less-specific programmes that are combined with workplace learning seem to be associated with a reduced advantage over time. Relying on the first overeducation indicator, our estimates suggest that the negative overeducation effect of having participated in such a programme (compared to a purely general programme) vanishes about 24 years $(0.848 / 0.035=24.2)$ after graduation. Based on the second overeducation indicator, this turning point is estimated to be 19 years only $(0.545 / 0.028=19.5)$ with the negative effect at the start of the career even being statistically insignificant. Alternatively, purely vocational programmes (i.e. those combining a specific focus with workplace learning) keep a relatively constant advantage in terms of avoiding overeducation throughout their career. Regarding overskilling, the results are somehow different, with purely vocational programmes showing the strongest reduction over time in their relatively advantage. However, since these programmes are also relatively more successful in avoiding overskilling at the start of the career, it takes more than 39 years $(1.879 / 0.048=39.1)$ before these programmes lose their advantage over purely general programmes. This is close to the end of a standard working career of 45 years.

Also in terms of avoiding undereducation (Table 1, Column (D)-(E)), some evidence of a trade-off is found. Those with a purely vocational programme are also less likely to be undereducated at the start of the career in comparison to those with a purely general education. Over time, this advantage diminishes resulting in an estimated turning point of 33 years $(0.433 / 0.013=33.3)$ to 36 years $(0.647 / 0.018=35.9)$ after graduation depending on the undereducation indicator. Alternatively, no evidence is found that a less-specific programme with workplace learning generates any advantage in terms of avoiding undereducation in comparison to purely general programmes. The results regarding specific programmes without workplace learning are somehow mixed, with only the second undereducation measure delivering evidence on a trade-off.

Finally, regarding underskilling and inadequate skilling, our analysis points to a trade-off that is opposite to the one found for the other mismatch types (Table 1, Column (F)-(G)). The results of specification (B) suggest that vocational programmes are associated with higher chances of underskilling and inadequate skilling at the start of the career and lower chances of these types of mismatch later on. However, specification (C) again reveals some differences between alternative types of vocational programmes, with particularly those with a less-specific programme that includes workplace learning facing problems of underskilling and inadequate skilling throughout their career. The other categories of vocational programmes seem to face less problems of 
underskilling and inadequate skilling. For instance, programmes that combine workplace learning with a specific orientation seem to have lower levels of inadequate skilling in the period beyond 16 years after graduation $(1.976 / 0.120=16.5)$

\subsection{Detailed types of skill mismatch (ESJS)}

While the aforementioned results pertain to overall educational and skill mismatches, the ESJS data also allow assessing mismatches in 11 more detailed types of skills. Table 2 reports the results for overskilling.

For five of the considered skills, the results of Specification (B) follow the pattern already observed for overall overskilling: a negative effect at the start of the career which diminishes over time and eventually becomes positive in the end. This is the case with respect to communication skills, customer handling skills, problem solving skills, learning skills and planning and organisation skills. However, while the simulated turning point in the case of overall overskilling was situated near the end of the working career, the turning point for these more detailed types of skills occurs already 18 to 26 years after graduation. Put differently, during (more than) half of the career, those with a vocational qualification seem to face more problems of overskilling for these skills than those with a general qualification. In addition, for technical skills, a positive interaction effect is combined with an insignificant main effect. This suggests that, apart from at the very beginning of the career, having a general rather than a vocational qualification is always advantageous in avoiding technical overskilling. Alternatively, regarding literacy, numeracy and foreign-language skills, those having participated in a vocational programme are less likely to be overskilled in comparison to those having participated in a general programme whatever the time elapsed since graduation. Overall, these results indicate that the turning point that was estimated for overall overskilling hides substantial heterogeneity in turning points for more detailed types of overskilling.

We also report results relying on Specification (C), in which vocational programmes are further subdivided into three distinct categories. These results are broadly in line with those for overall overskilling, suggesting that purely vocational programmes and specific programmes without workplace learning are the most successful in avoiding initial overskilling in terms of many of these more detailed types of skills. However, for most of these skills, these programmes also face a decline in this advantage over time. Alternatively, programmes that combine workplace learning with a less-specific curriculum are not found to be statistically different from purely general programmes in terms of these more detailed types of overskilling. 
The results on detailed types of underskilling are reported in the online Appendix 2. Only a few statistically significant effects can be detected. We find those having participated in a vocational programme to be less likely to face underskilling in terms of technical skills than those having participated in a general programme. A similar result is found in the case of ICT skills, but only for vocational programmes without workplace learning. Only regarding underskilling in terms of team working, some evidence for a trade-off effect is found. Less-specific programmes with workplace learning and specific programmes without workplace learning are found to combine lower levels of initial underskilling in terms of team working with higher levels of this type of underskilling later on.

\subsection{Differences across countries (ESJS)}

Table 3 reports estimates on overeducation (definition 2) and overall overskilling for different groups of countries. Given the smaller sample sizes, we confine our analysis to estimating specifications with one overall vocational programme category dummy.

First, we look at whether the results depend on the vocational system of the country (Table 3, Column (A)-(D)). On the basis of Specification (A), a clear pattern emerges with the negative effects on both overeducation and general overskilling being more pronounced in education systems with a stronger vocational orientation. The results on the basis of Specification (B) differ somehow between the two mismatch indicators. For overeducation, evidence on a trade-off effect is found only for the non-vocational countries. For overskilling, however, a clear pattern emerges again with both the initial effect and the interaction effect being the strongest (weakest) in the dual system (non-vocational) countries. To test whether these differences are statistically significant, we also estimate models based on the full set of countries and with additional interaction terms between all the variables and a dummy for the traditional dual system countries. These estimates, which are reported in online Appendix 3, support that the trade-off effects regarding overall overskilling are stronger for dual system countries than for other countries.

To account for changes in vocational curricula in many former communist countries, we also check whether the results differ between Western-European and Central- and Eastern-European countries (Table 3, Column (E)-(F)). While all coefficients have the expected sign for both groups of countries and for both mismatch indicators, the interaction effects between vocational education and the time since graduation are statistically significant only for the Western European Countries. However, additional test results, reported in online 
Appendix 3, do not reveal significant differences between the two groups of countries. Finally, given the educational reforms that were implemented in the past in Sweden and The Netherlands, we also re-estimate our models by excluding these countries (see online Appendix 4). Regarding overall overskilling, this does not change the results substantively. Also regarding overeducation, coefficients are similar, although the interaction effect between vocational education and the time since graduation is no longer statistically significant on the basis of this reduced sample.

\subsection{Additional evidence on the basis of PIAAC}

To assess the robustness of our findings and the role of selectivity, we end with some additional evidence based on the PIAAC data. The results are reported in table 4.

First, we look at over- and undereducation. The results based on Specification (A), which only includes a vocational education dummy along with the standard control variables, indicate that individuals with a vocational programme on average have higher levels of overeducation and lower levels of undereducation in comparison to those with a general qualification. While the ESJS data delivered a similar result for undereducation, the opposite conclusion was made for overeducation. In specification (B), we also include an interaction effect between vocational education and the time since graduation. Whereas the interaction effect on undereducation is statistically insignificant, the results for overeducation confirm those based on the ESIS: a negative initial effect and a positive interaction effect with the time since graduation. However, the turning point appears to occur already 14 years $(0.525 / 0.037=14.2)$ after graduation, which is substantially earlier than what was found for overeducation and overall overskilling with the ESJS data. ${ }^{8}$

Next, we add controls for social background to account for selectivity (Table 4, Column (C)). This increases the negative coefficient regarding the initial effect of vocational education on overeducation, suggesting that those with a vocational qualification are negatively selected in terms of characteristics that reduce the likelihood to be overeducated. Most importantly, however, the interaction effect with the time since graduation is hardly

\footnotetext{
${ }^{8}$ Relying for the ESJS on Specification (B), the estimated turning points for overeducation (Definition 2) and overall overskilling are 50.6 years $(0.709 / 0.014)$ and 41.5 years (1.452/0.035) after graduation respectively (see Table 1$)$. Given the difference in composition of both datasets, we also estimated these models by relying on an identical set of countries. These results are reported in online Appendix 5 . While the sizes of the coefficients and their significance differ somewhat from what is found on the basis of the full datasets, this does not affect our conclusion concerning the considerable differences in estimated turning points between both datasets.
} 
affected. Finally, we also control for numeracy skills (Specification (D)). The level of numeracy skills has a strong negative effect on the degree of overeducation and a strong positive effect on the degree of undereducation. This aligns with earlier findings in the literature (e.g. Green et al., 1999). However, while adding this control further increases the initial negative effect, it again hardly affects the interaction effect in the case of overeducation.

We also report results for numeracy and literacy overskilling relying on PIAAC. While caution is recommended given the shortcomings of these measures, the results are in line with our hypothesis and suggest that those with a vocational qualification face lower levels of these types of overskilling at the start of the career and higher levels at the end of the career. Adding controls for social background and skills reduces (but not completely erases) the estimated initial effects, resulting from the fact that higher levels of numeracy and literacy skills increase levels of overskilling in terms of these types of skills. However, the estimated interaction effects between the vocational education dummy and the time since graduation are again hardly affected. Regarding literacy overskilling, this interaction effect even increases after adding these controls, suggesting that selectivity rather underestimates the relative increase in this type of mismatch over time for vocationally educated individuals.

Overall, these results indicate that selection is of little importance in explaining the positive interaction effect between vocational education and the time since graduation on mismatches. As a final check, we also conduct a more formal coefficient stability test as recently developed by Oster (2017). The test looks at how important the unobservables should be relative to key observable variables in explaining the estimated baseline treatment effect in order to have a true treatment effect of zero. Given that our coefficient of interest is an interaction effect, we implement a modification of the test as proposed by Hanushek et al. (2017). More specifically, we look separately at the effect of vocational education on overeducation for relatively recent graduates $(<=20$ years since graduation) and for relatively old graduates ( $>20$ years since graduation). The procedure and results are reported in more detail in online Appendix 6. In line with our interaction specification, recent (older) graduates with a vocational qualification are found to be less (more) likely to be overeducated than recent (older) graduates with a general qualification. Further, the test statistics suggest that the negative effect on overeducation for recent graduates is underestimated because of selection on unobservables, while the positive effect for older graduates is overestimated. However, the test also suggests that the relative difference in estimated effects between recent and older graduates is relatively unaffected by unobservables. 


\section{Discussion and conclusion}

The main aim of this study was to investigate whether the orientation of secondary education programmes in terms of vocationalism involves a trade-off between short-run and long-run effects on educational and skills mismatches. To this end, we exploited the information contained in two different datasets: ESJS and PIAAC. Relying primarily on ESJS allowed us to develop different measures of educational mismatches and skill mismatches in a detailed way, and to differentiate between the role of the specificity of the programme and the role of workplace learning. Supplementing these with analyses based on PIAAC allowed us to account for bias resulting from differences in cognitive skills between participants in vocational and general programmes (PIAAC).

In general, our results were in line with expectations. At the start of their careers, we found workers with a vocational qualification, on average, to have a lower degree of over- and undereducation and a lower degree of overskilling. Moreover, this lower degree of overskilling was observed both in overall terms and in terms of many more detailed types of skills such as planning and organisation skills or customer handling skills. These findings largely align with the idea that young labour market entrants with a vocational qualification are more employable due to the focus of their education on skills that are immediately usable and are in demand on the labour market. However, we also found that many (but not all) of these mitigating effects of vocational programmes on mismatches diminish with the time elapsed since graduation. This supports the hypothesis that the skills learned in vocational education gradually become obsolete because of structural and organisational changes on the labour market. Over time, general skills may be more advantageous if they allow workers to adapt to changing skill requirements.

Differentiating between different types of vocational programmes in terms of their specificity and their focus on workplace learning, we clearly found the most favourable effects in terms of avoiding mismatches in programmes that combine a specific focus with workplace learning (i.e. purely vocational programmes). We also found more favourable effects for vocational programmes in dual system countries. These results align with the findings of Hanushek et al. (2017) regarding the effects of vocational education on employment, and they are consistent with the idea that the advantage of vocational programmes should be stronger as the "treatment intensity" increases. Alternatively, vocational programmes that combine a less-specific focus with workplace learning seem to be less effective in terms of avoiding overeducation and overskilling. This conclusion aligns with those of Verhaest and Baert (2017). When differentiating between vocational and general programmes in higher 
education on the basis of the presence of curriculum-based work placement, they did not find clear effects either. Moreover, our results suggest that less-specific programmes with workplace learning are associated with higher levels of overall underskilling and 'inadequate' skilling in comparison with 'purely' general programmes. It thus seems that the value-added of workplace learning is limited when it is not embedded in a programme with a clear focus.

The extent to which purely vocational programmes are more efficient in avoiding mismatch than purely general programmes crucially depends on the timing of the turning point, i.e. the age at which having a purely vocational qualification starts to become disadvantageous. Regarding overall overskilling, we found this advantage to disappear (and eventually to turn in a disadvantage) only by the end of the working career. Regarding overeducation, we even found this advantage to persist throughout the career when relying on the ESJS data. Finally, while the turning point for vocational programmes was estimated to be below half of a standard career of 45 years for overeducation when relying on PIAAC, additional test results also suggested this turning point to be substantially underestimated due to differences in unobservable characteristics with general education graduates. If so, the implication would be that purely vocational programmes are indeed to be preferred from a career perspective. Yet, for several reasons, caution is recommended regarding this conclusion. First of all, this conclusion pertains to overall surpluses of education and skills only. For many of the more detailed types of overskilling, turning points were estimated to emerge much earlier in the career. Secondly, the estimates on both the initial effects and the interaction effects on overeducation and overskilling were relatively imprecise while even small changes in their value may generate a radically different conclusion regarding the turning point. Thirdly, the results on deficits of education and skills were more mixed, with a similar trade-off effect being found for undereducation but not for underskilling and inadequate skilling.

Overall, our results suggest that implementing vocational programmes which combine a specific focus with workplace learning is an effective way to avoid most (but not all) types of educational and skill mismatches during the first part of the career of medium skilled workers. From a life-cycle perspective, however, this advantage is less evident. This conclusion complements other studies finding similar results in terms of employment and earnings. Moreover, given that mismatches are also found to have a negative effect on wages and employment chances, both results are likely to be connected. Investigating the extent to which this is the case would therefore be an interesting avenue for further research. Finally, also further research on the role of 
specific mechanisms underlying the relationship between the orientation of one's formal education and skill mismatches, such as differences in informal training participation and its effects, would be illuminating.

\section{Supplementary material}

Supplementary material is available online at the OUP website. This includes an online appendix. The initial ESJS data used in this paper were confidential when the project was initiated, but a public use file is now available conditional on completion of an online access registration form at: http://www.cedefop.europa.eu/en/eventsand-projects/projects/european-skills-and-jobs-esj-survey/access-to-data. The public use file of the PIAAC data can be downloaded from http://www.oecd.org/skills/piaac/publicdataandanalysis/. The replication files are also available online.

\section{Funding}

This work was supported by the Flemish government within the frame of the Policy Research Centre on Studyand School careers (Steunpunt SSL).

\section{Acknowledgements}

We are grateful to seminar participants at the University of Sheffield, to Wilfried Boomgaert and to two anonymous referees for their helpful comments and suggestions.

\section{References}

Allen, J., Levels, M., and Van der Velden, R. (2013). Skill mismatch and skill use in developed countries: Evidence from the PIAAC study. ROA Research Memoranda, 17, Maastricht: Research Centre for Education and the Labour Market.

Allen, J., and Van der Velden, R. (2001). Educational mismatches versus skill mismatches: effects on wages, job satisfaction, and on-the-job search. Oxford Economic Papers, 53, 434-452.

Artés, J., Salinas-Jiménez, M., and Salinas-Jiménez, J. (2014). Small fish in a big pond or big fish in a small pond? The effects of educational mismatch on subjective wellbeing. Social Indicators Research, 119, 771-789.

Arum, R., and Shavit, Y. (1995). Vocational education and the transition of men and women from school to work. Sociology of Education, 68, 187-204. 
Bender, K., and Heywood, J. (2017). Educational mismatch and retirement. Education Economics, 25, 347365.

Bracke, P., Pattyn, E., and von dem Knesebeck, O. (2013). Overeducation and depressive symptoms: diminishing mental health returns to education. Sociology of Health \& IIIness, 35, 1242-1259.

Brunello, G., and Rocco, L. (2017). The Labor Market Effects of Academic and Vocational Education over the Life Cycle: Evidence Based on a British Cohort. Journal of Human Capital, 11, 106-166.

Cedefop (2015). Skills, qualifications and jobs in the EU: the making of a perfect match? Evidence from Cedefop's European skills and jobs survey. Luxembourg: Publications Office of the European Union.

Dolton, P., and Silles, M. (2003). The determinants and consequences of graduate overeducation. In F. Büchel, A. de Grip and A. Mertens (eds), Overeducation in Europe, Current Issues in Theory and Policy, Edward Elgar, 189-213.

Eurostat (2016). Vocational education and training statistics. Retrieved from http://ec.europa.eu /eurostat/statistics-explained/index.php/Vocational_education_and_training_statistics on 31/10/2017.

Forster, A., Bol, R., and van de Werfhorst, H. (2016). Vocational education and employment over the Life cycle. Sociological Science, 3, 473-494.

Giret, J. (2011). Does vocational training help transition to work? The 'New French Vocational Bachelor Degree'. European Journal of Education, 46, 244-256.

Goldin, C. (2001). The human-capital century and American leadership: virtues of the past. Journal of Economic History, 61, 263-292.

Green, F., and Mclntosh, S. (2007). Is there a genuine under-utilization of skills amongst the overqualified? Applied Economics, 39, 427-439.

Green, F., Mclntosh, S., and Vignoles, A. (1999). 'Overeducation' and skills - Clarifying the concepts. Centre for Economic Performance Discussion Paper, 435.

Green, F., and Zhu, Y. (2010). Overqualification, job dissatisfaction, and increasing dispersion in the returns to graduate education. Oxford Economic Papers, 62, 740-763

Hampf, F., and Woessmann, L. (2017). Vocational vs. general education and employment over the life- 
cycle: new evidence from PIAAC. Cesifo Economic Studies, 63, 255-269.

Hanushek, E., Schwerdt, G., Woessmann, L., and Zhang, L. (2017). General education, vocational education, and labour-market outcomes over the life-cycle. Journal of Human Resources, 52, 48-87.

Hartog, J. (2000). Over-education and earnings: where are we, where should we go? Economics of Education Review, 19, 131-147.

Hayward, G. (2004). Foreword: a century of vocationalism. Oxford Review of Education, 30 (1), 3-12.

Heijke, H., Meng, C., and Ris, C. (2003). Fitting to the job: the role of generic and vocational competencies in adjustment and performance. Labour Economics, 10, 215-229.

Jerrim, J., Lopez-Agudo, L., Marcenaro-Gutierrez, O., and Shure, N. (2017). What happens when econometrics and psychometrics collide? An example using the PISA data. Economics of Education Review, 61, 51-58.

Kogan, I. (2008). Education systems of Central and Eastern European countries. In I. Kogan, M. Gebel \& C. Noelke (eds), Europe enlarged: A handbook of education, labour and welfare regimes in Central and Eastern Europe, Bristol: Policy Press, 7-34.

Krueger, D., and Kumar, K. (2004). Skill-specific rather than general education: a reason for US-Europe growth differences? Journal of Economic Growth, 9, 167-207.

Lavrijsen, J., and Nicaise, I. (2017). Returns on vocational education over the life cycle: between immediate labour market preparation and lifelong employability. International Review of Education, 63, 257280.

Levels, M., van der Velden, R., and Allen, J. (2014). Educational mismatches and skills: new empirical tests of old hypotheses. Oxford Economic Papers, 66, 959-982.

Levels, M., van der Velden, R., and Di Stasio, V. (2014). From school to fitting work: How education-to-job matching of European school leavers is related to educational system characteristics. Acta Sociologica, 57, 341361.

Mavromaras, K., McGuinness, S., O'Leary, N., Sloane, P., and Wei, Z. (2013). Job mismatches and labour market outcomes: panel evidence on university graduates. Economic Record, 89, 382-395. 
Mavromaras, K., Sloane, P., and Wei, Z. (2015). The scarring effects of unemployment, low pay and skills under-utilization in Australia compared. Applied Economics, 47, 2413-2429.

McGuinness, S. (2006). Over-education in the labour market. Journal of Economic Surveys, 20, 387-418.

McGuinness, S., and Wooden, M. (2009). Overskilling, job insecurity and career mobility. Industrial Relations, 48, 265-286.

Müller, W., and Gangl, M. (2003). The transition from school to work: a European perspective. In W. Müller \& M. Gangl (eds), Transitions from Education to Work in Europe, Oxford: Oxford University Press, 1-19.

OECD (2013). OECD Skills Outlook 2013. Paris: Organisation for Economic Co-operation and Development.

OECD (2014). Education at a Glance 2014. Paris: Organisation for Economic Co-operation and Development.

Oster, E. (2017). Unobservable Selection and Coefficient Stability: Theory and Evidence. Journal of Business \& Economic Statistics, forthcoming. DOI: 10.1080/07350015.2016.1227711

Piper, A. (2015). Heaven knows I'm miserable now: overeducation and reduced life satisfaction. Education Economics, 23, 677-692.

Rubb, S. (2003). Overeducation in the labor market: a comment and re-analysis of a meta-analysis. Economics of Education Review, 22, 621-629.

Ryan, P. (2001). The school-to-work transition: a cross-national perspective. Journal of Economic Literature, 39, 34-92.

Sicherman, N., and Galor, O. (1990). A theory of career mobility. Journal of Political Economy, 98, 169192.

Sloane, P., Battu, H., and Seaman, P. (1999). Overeducation, undereducation and the British labour market. Applied Economics, 31, 1437-1453.

Stenberg, A., and Westerlund, O. (2015). The long-term earnings consequences of general vs. specific training of the unemployed. IZA Journal of European Labor Studies, 4, 22.

Verhaest, D., and Baert, S. (2017). The effects of workplace learning in higher education on employment 
and match quality: Is there an early-career trade-off? Empirical Economics, forthcoming. DOI: 10.1007/s00181017-1308-4

Verhaest, D., and Omey, E. (2013). The relationship between formal education and skill acquisition in young workers' first jobs. The Manchester School, 81 (4), 638-659.

Verhaest, D., Schatteman, T., and Van Trier, W. (2015). Overeducation in the early career of secondary education graduates: an analysis using sequence techniques. Young, 23 (4), 336-356.

Verhaest, D., and van der Velden, R. (2013). Cross-country differences in graduate overeducation. European Sociological Review, 29, 642-653.

Zhu, R., and Chen, L. (2016). Overeducation, overskilling and mental well-being. The B.E. Journal of Economic Analysis \& Policy, 16. 
Table 1 The impact of the programme orientation on overall educational and skill mismatches (ESJS) - Tobit or linear regression coefficients

\begin{tabular}{|c|c|c|c|c|c|c|c|c|c|c|c|c|c|c|}
\hline Specification (A) & \multicolumn{2}{|c|}{$\begin{array}{c}\text { (A) } \\
\text { Overeducation } \\
\text { (Definition 1) }\end{array}$} & \multicolumn{2}{|c|}{$\begin{array}{c}\text { (B) } \\
\text { Overeducation } \\
\text { (Definition 2) }\end{array}$} & \multicolumn{2}{|c|}{$\begin{array}{c}\text { (C) } \\
\text { Overskilling }\end{array}$} & \multicolumn{2}{|c|}{$\begin{array}{l}\text { (D) } \\
\text { Undereducation } \\
\text { (Definition 1) }\end{array}$} & \multicolumn{2}{|c|}{$\begin{array}{c}(\mathrm{E}) \\
\text { Undereducation } \\
\text { (Definition 2) }\end{array}$} & \multicolumn{2}{|c|}{$\begin{array}{l}\text { (F) } \\
\text { Inderskilling }\end{array}$} & \multicolumn{2}{|c|}{$\begin{array}{c}(\mathrm{G}) \\
\text { Inadequate Skilling }\end{array}$} \\
\hline $\begin{array}{l}\text { Vocational } \\
\text { Specification (B) }\end{array}$ & -0.514 & $(0.083)^{* * *}$ & -0.410 & $(0.087)^{* * *}$ & -0.664 & $(0.126)^{* * *}$ & -0.088 & $(0.067)$ & -0.160 & $(0.061)^{* * *}$ & 0.199 & $(0.207)$ & -0.562 & (0.388) \\
\hline Vocational & -0.732 & $(0.182)^{* * *}$ & -0.709 & $(0.184)^{* * *}$ & -1.452 & $(0.284)^{* * *}$ & -0.245 & $(0.157)$ & -0.491 & $(0.148)^{* * *}$ & 1.016 & $(0.453)^{* *}$ & 2.093 & $(0.872)^{* *}$ \\
\hline $\begin{array}{l}\text { Vocational * Time since graduation } \\
\text { Specification }(C)\end{array}$ & 0.010 & $(0.008)$ & 0.014 & $(0.008)^{*}$ & 0.035 & $(0.012)^{* * *}$ & 0.007 & $(0.006)$ & 0.014 & $(0.006)^{* *}$ & -0.036 & $(0.018)^{* *}$ & -0.117 & $(0.036)^{* * *}$ \\
\hline Workplace learning - Not specific & -0.848 & $(0.376)^{* *}$ & -0.545 & $(0.384)$ & -1.321 & $(0.558)^{* *}$ & 0.246 & (0.329) & 0.092 & $(0.300)$ & 1.701 & $(0.916)^{*}$ & 5.442 & $(1.845)^{* * *}$ \\
\hline No workplace learning - Specific & -0.754 & $(0.203)^{* * *}$ & -0.913 & $(0.205)^{* * *}$ & -1.097 & $(0.316)^{* * *}$ & -0.171 & $(0.172)$ & -0.460 & $(0.161)^{* * *}$ & 0.972 & $(0.497)^{*}$ & 1.578 & $(0.968)$ \\
\hline Workplace learning and Specific & -0.704 & $(0.209)^{* * *}$ & -0.544 & $(0.210)^{* *}$ & -1.879 & $(0.318)^{* * *}$ & -0.433 & $(0.179)^{* *}$ & -0.647 & $(0.168)^{* * *}$ & 0.859 & $(0.500)^{*}$ & 1.976 & $(0.961)^{* *}$ \\
\hline $\begin{array}{l}\text { Workplace learning - Not specific } \\
* \text { Time since graduation }\end{array}$ & 0.035 & $(0.016)^{* *}$ & 0.028 & $(0.016)^{*}$ & 0.037 & $(0.024)$ & -0.007 & $(0.014)$ & -0.002 & $(0.012)$ & -0.024 & (0.039) & -0.144 & $(0.079)^{*}$ \\
\hline $\begin{array}{l}\text { No workplace learning - Specific } \\
* \text { Time since graduation }\end{array}$ & 0.011 & $(0.008)$ & 0.020 & $(0.008)^{* *}$ & 0.024 & $(0.013)^{*}$ & 0.004 & $(0.006)$ & 0.013 & $(0.006)^{* *}$ & -0.040 & $(0.020)^{* *}$ & -0.104 & $(0.039)^{* * *}$ \\
\hline $\begin{array}{l}\text { Workplace learning and Specific } \\
* \text { Time since graduation }\end{array}$ & 0.003 & $(0.009)$ & 0.005 & $(0.009)$ & 0.048 & $(0.013)^{* * *}$ & 0.013 & $(0.007)^{*}$ & 0.018 & $(0.007)^{* * *}$ & -0.030 & $(0.021)$ & -0.120 & $(0.040)^{* * *}$ \\
\hline N & & 887 & & 874 & & 462 & & 887 & & 874 & & 469 & & 548 \\
\hline
\end{tabular}

Notes: Columns (A)-(D) are based on tobit regression; column (E) is based on linear regression. Control variables included in all regressions are gender, age, time since graduation, time since graduation squared, country dummies, level of education. Data are weighted using sampling weights and giving same weight to each country. ${ }^{*}\left({ }^{* *}\right)\left(\left({ }^{* * *}\right)\right)$ indicates significance at the $10 \%(5 \%)((1 \%))$ significance level. Robust standard errors in parentheses.

Source: ESJS - Authors' calculations. 
Table 2 The impact of the programme orientation on detailed types of overskilling (ESJS) - Tobit regression coefficients

\begin{tabular}{|c|c|c|c|c|c|c|c|c|c|c|c|}
\hline & Numeracy & Literacy & ICT & Technical & $\begin{array}{l}\text { Communi- } \\
\text { cation }\end{array}$ & $\begin{array}{l}\text { Team- } \\
\text { Working }\end{array}$ & $\begin{array}{l}\text { Foreign- } \\
\text { Language }\end{array}$ & $\begin{array}{l}\text { Customer } \\
\text { handling }\end{array}$ & $\begin{array}{l}\text { Problem } \\
\text { Solving }\end{array}$ & Learning & $\begin{array}{l}\text { Planning and } \\
\text { Organisation }\end{array}$ \\
\hline \multicolumn{12}{|l|}{ Specification (A) } \\
\hline & $\begin{array}{l}-0.165 \\
(0.061)^{* * *}\end{array}$ & $\begin{array}{l}-0.214 \\
(0.059)^{* * *}\end{array}$ & $\begin{array}{l}-0.032 \\
(0.062)\end{array}$ & $\begin{array}{l}0.246 \\
(0.059)^{* * *}\end{array}$ & $\begin{array}{l}-0.026 \\
(0.053)\end{array}$ & $\begin{array}{l}0.070 \\
(0.053)\end{array}$ & $\begin{array}{l}-0.229 \\
(0.081)^{* * *}\end{array}$ & $\begin{array}{c}0.063 \\
(0.063)\end{array}$ & $\begin{array}{c}0.048 \\
(0.054)\end{array}$ & $\begin{array}{c}0.026 \\
(0.053)\end{array}$ & $\begin{array}{l}0.044 \\
(0.056)\end{array}$ \\
\hline \multicolumn{12}{|l|}{ Specification (B) } \\
\hline Vocational & $\begin{array}{l}-0.223 \\
(0.141)\end{array}$ & $\begin{array}{l}-0.314 \\
(0.129)^{* *}\end{array}$ & $\begin{array}{l}-0.211 \\
(0.142)\end{array}$ & $\begin{array}{l}-0.042 \\
(0.132)\end{array}$ & $\begin{array}{l}-0.332 \\
(0.118)^{* * *}\end{array}$ & $\begin{array}{l}-0.084 \\
(0.122)\end{array}$ & $\begin{array}{l}-0.333 \\
(0.184)^{*}\end{array}$ & $\begin{array}{l}-0.266 \\
(0.137)^{*}\end{array}$ & $\begin{array}{l}-0.218 \\
(0.116)^{*}\end{array}$ & $\begin{array}{l}-0.256 \\
(0.120)^{* *}\end{array}$ & $\begin{array}{l}-0.258 \\
(0.124)^{* *}\end{array}$ \\
\hline $\begin{array}{l}\text { Vocational * Time since } \\
\text { graduation }\end{array}$ & $\begin{array}{l}0.003 \\
(0.006)\end{array}$ & $\begin{array}{c}0.004 \\
(0.005)\end{array}$ & $\begin{array}{c}0.008 \\
(0.006)\end{array}$ & $\begin{array}{l}0.013 \\
(0.005)^{* *}\end{array}$ & $\begin{array}{l}0.013 \\
(0.005)^{* * *}\end{array}$ & $\begin{array}{l}0.007 \\
(0.005)\end{array}$ & $\begin{array}{l}0.005 \\
(0.007)\end{array}$ & $\begin{array}{l}0.015 \\
(0.006)^{* * *}\end{array}$ & $\begin{array}{l}0.012 \\
(0.005)^{* *}\end{array}$ & $\begin{array}{l}0.012 \\
(0.005)^{* *}\end{array}$ & $\begin{array}{l}0.013 \\
(0.005)^{* * *}\end{array}$ \\
\hline \multicolumn{12}{|l|}{ Specification (C) } \\
\hline Workplace learning - Not specific & $\begin{array}{l}0.093 \\
(0.261)\end{array}$ & $\begin{array}{l}-0.165 \\
(0.253)\end{array}$ & $\begin{array}{l}-0.016 \\
(0.272)\end{array}$ & $\begin{array}{c}0.250 \\
(0.252)\end{array}$ & $\begin{array}{l}-0.023 \\
(0.237)\end{array}$ & $\begin{array}{l}0.165 \\
(0.233)\end{array}$ & $\begin{array}{l}-0.241 \\
(0.359)\end{array}$ & $\begin{array}{l}-0.187 \\
(0.256)\end{array}$ & $\begin{array}{l}-0.079 \\
(0.221)\end{array}$ & $\begin{array}{l}-0.132 \\
(0.211)\end{array}$ & $\begin{array}{l}0.002 \\
(0.243)\end{array}$ \\
\hline No workplace learning - Specific & $\begin{array}{l}-0.210 \\
(0.154)\end{array}$ & $\begin{array}{l}-0.349 \\
(0.142)^{* *}\end{array}$ & $\begin{array}{l}-0.125 \\
(0.152)\end{array}$ & $\begin{array}{l}-0.057 \\
(0.143)\end{array}$ & $\begin{array}{l}-0.368 \\
(0.129)^{* * *}\end{array}$ & $\begin{array}{l}-0.019 \\
(0.133)\end{array}$ & $\begin{array}{l}-0.344 \\
(0.199)^{*}\end{array}$ & $\begin{array}{l}-0.323 \\
(0.151)^{* *}\end{array}$ & $\begin{array}{l}-0.203 \\
(0.127)\end{array}$ & $\begin{array}{l}-0.282 \\
(0.132)^{* *}\end{array}$ & $\begin{array}{l}-0.257 \\
(0.135)^{*}\end{array}$ \\
\hline Workplace learning and Specific & $\begin{array}{l}-0.285 \\
(0.157)^{*}\end{array}$ & $\begin{array}{l}-0.300 \\
(0.146)^{* *}\end{array}$ & $\begin{array}{l}-0.334 \\
(0.158)^{* *}\end{array}$ & $\begin{array}{l}-0.069 \\
(0.146)\end{array}$ & $\begin{array}{l}-0.331 \\
(0.133)^{* *}\end{array}$ & $\begin{array}{l}-0.188 \\
(0.137)\end{array}$ & $\begin{array}{l}-0.327 \\
(0.206)\end{array}$ & $\begin{array}{l}-0.281 \\
(0.152)^{*}\end{array}$ & $\begin{array}{l}-0.262 \\
(0.129)^{* *}\end{array}$ & $\begin{array}{l}-0.243 \\
(0.133)^{*}\end{array}$ & $\begin{array}{l}-0.292 \\
(0.139)^{* *}\end{array}$ \\
\hline $\begin{array}{l}\text { Workplace learning - Not specific } \\
\text { * Time since graduation }\end{array}$ & $\begin{array}{l}-0.008 \\
(0.012)\end{array}$ & $\begin{array}{c}0.002 \\
(0.011)\end{array}$ & $\begin{array}{c}0.004 \\
(0.012)\end{array}$ & $\begin{array}{l}-0.004 \\
(0.011)\end{array}$ & $\begin{array}{l}-0.002 \\
(0.010)\end{array}$ & $\begin{array}{l}-0.009 \\
(0.011)\end{array}$ & $\begin{array}{c}0.005 \\
(0.016)\end{array}$ & $\begin{array}{l}-0.002 \\
(0.011)\end{array}$ & $\begin{array}{c}0.005 \\
(0.010)\end{array}$ & $\begin{array}{c}0.007 \\
(0.009)\end{array}$ & $\begin{array}{l}-0.002 \\
(0.011)\end{array}$ \\
\hline $\begin{array}{l}\text { No workplace learning - Specific } \\
\text { * Time since graduation }\end{array}$ & $\begin{array}{l}0.004 \\
(0.006)\end{array}$ & $\begin{array}{c}0.007 \\
(0.006)\end{array}$ & $\begin{array}{c}0.007 \\
(0.006)\end{array}$ & $\begin{array}{l}0.012 \\
(0.006)^{* *}\end{array}$ & $\begin{array}{l}0.015 \\
(0.005)^{* * *}\end{array}$ & $\begin{array}{l}0.004 \\
(0.005)\end{array}$ & $\begin{array}{c}0.008 \\
(0.008)\end{array}$ & $\begin{array}{l}0.015 \\
(0.006)^{* *}\end{array}$ & $\begin{array}{l}0.010 \\
(0.005)^{*}\end{array}$ & $\begin{array}{l}0.014 \\
(0.005)^{* *}\end{array}$ & $\begin{array}{l}0.013 \\
(0.005)^{* *}\end{array}$ \\
\hline $\begin{array}{l}\text { Workplace learning and Specific } \\
\text { * Time since graduation }\end{array}$ & $\begin{array}{c}0.001 \\
(0.006)\end{array}$ & $\begin{array}{c}0.002 \\
(0.006)\end{array}$ & $\begin{array}{c}0.008 \\
(0.007)\end{array}$ & $\begin{array}{l}0.017 \\
(0.006)^{* * *}\end{array}$ & $\begin{array}{l}0.013 \\
(0.006)^{* *}\end{array}$ & $\begin{array}{l}0.012 \\
(0.006)^{* *}\end{array}$ & $\begin{array}{l}-0.002 \\
(0.009)\end{array}$ & $\begin{array}{l}0.018 \\
(0.006)^{* * *}\end{array}$ & $\begin{array}{l}0.016 \\
(0.005)^{* * *}\end{array}$ & $\begin{array}{l}0.012 \\
(0.006)^{* *}\end{array}$ & $\begin{array}{l}0.016 \\
(0.006)^{* * *}\end{array}$ \\
\hline $\mathrm{N}$ & 13381 & 13928 & 13005 & 14831 & 14988 & 15019 & 12983 & 13870 & 15065 & 15060 & 14769 \\
\hline
\end{tabular}

Notes: Control variables included in all regressions are gender, age, time since graduation, time since graduation squared, country dummies, level of education. Data are weighted using sampling weights and giving same weight to each country. ${ }^{*}\left(^{* *}\right)\left(\left({ }^{* * *}\right)\right)$ indicates significance at the $10 \%(5 \%)((1 \%))$ significance level. Robust standard errors in parentheses.

Source: ESJS - Authors' calculations. 
Table 3 The impact of the programme orientation on overeducation and overall overskilling across different country groups (ESJS) - Tobit regression coefficients

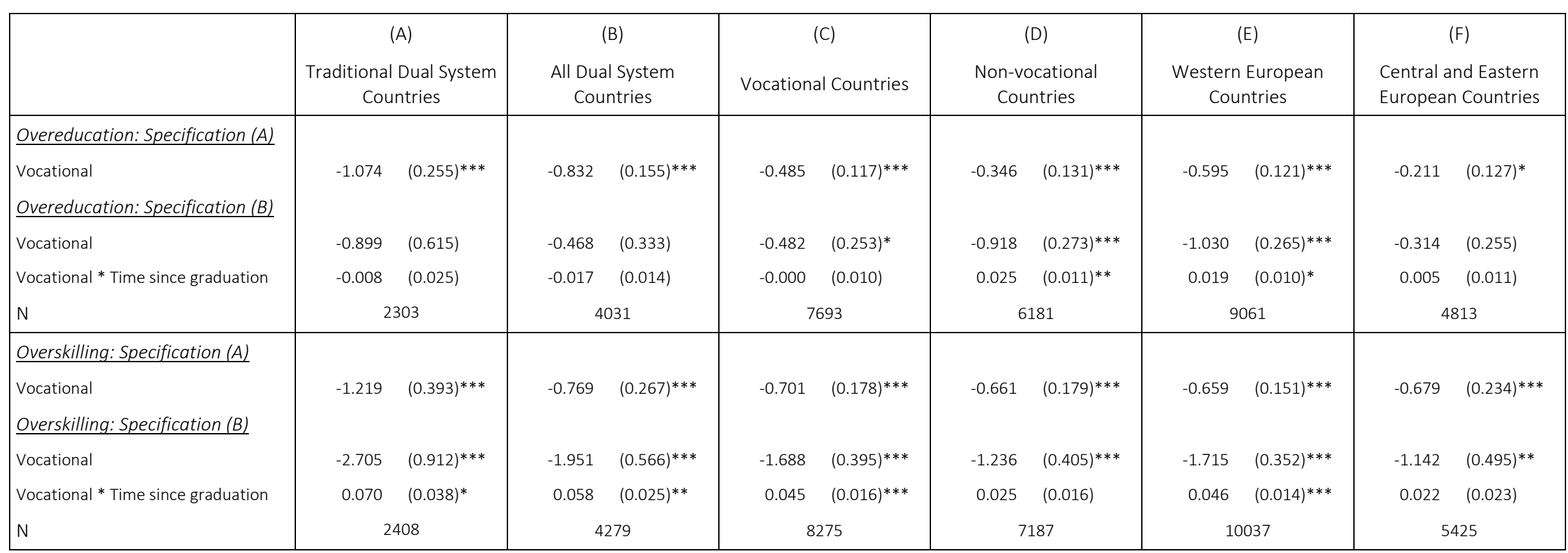

Notes: Control variables included in all regressions are gender, age, time since graduation, time since graduation squared, country dummies, level of education. Overeducation is measured based on Definition 2. (B) includes Austria, Denmark, Germany and Luxembourg; (C) includes (B) + Czech Republic, Hungary, Romania and Slovenia; (D) includes (C) + Belgium, Bulgaria, Croatia, Finland, Italy, The Netherlands and Slovakia; (E) includes all remaining EU countries. Data are weighted using sampling weights and giving same weight to each country. ${ }^{*}\left({ }^{* *}\right)\left(\left({ }^{* * *}\right)\right)$ indicates significance at the $10 \%(5 \%)((1 \%))$ significance level. Robust standard errors in parentheses.

Source: ESJS - Authors' calculations. 
Table 4 The impact of the programme orientation on educational mismatches (PIAAC) - tobit regression coefficients

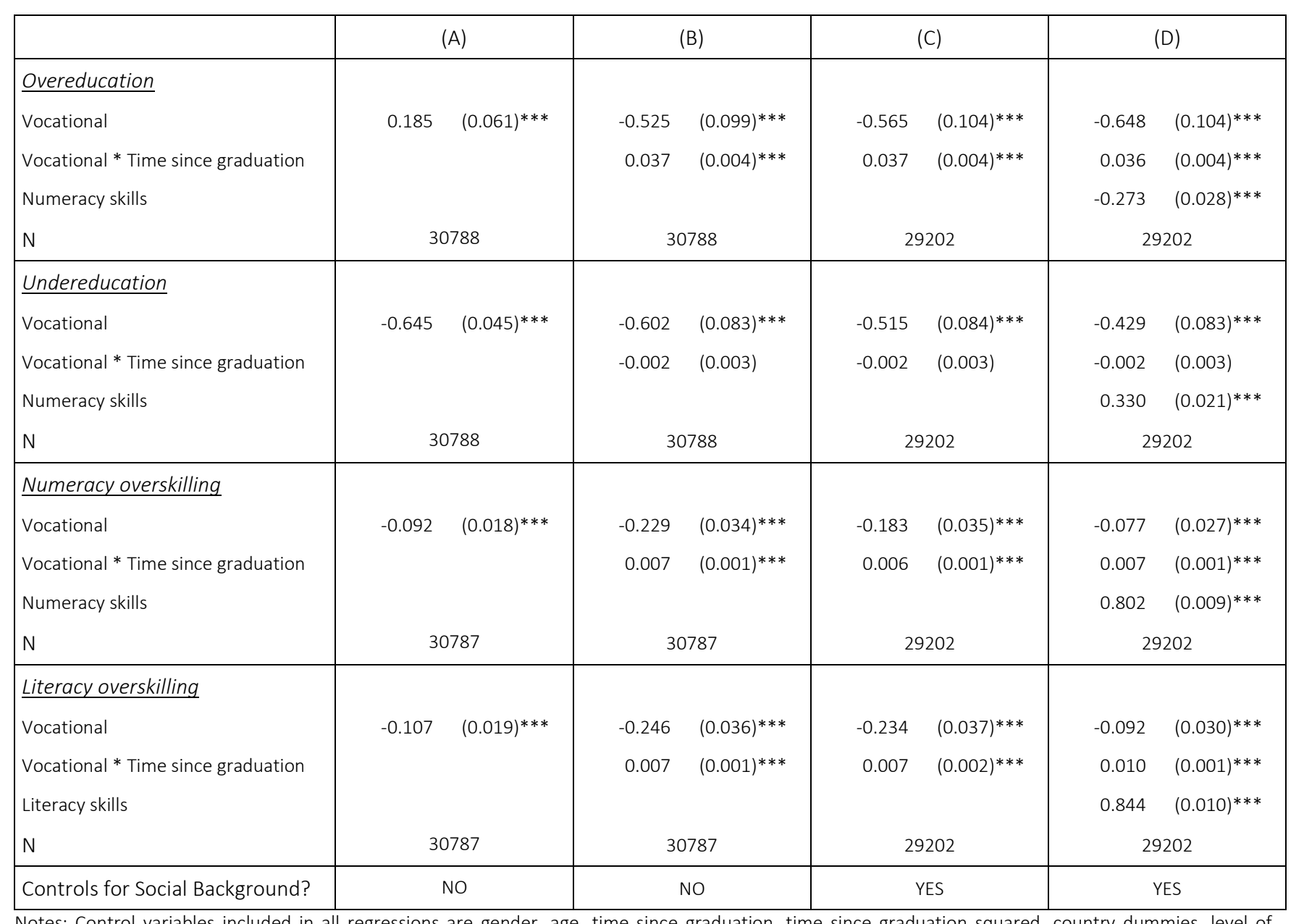

Notes: Control variables included in all regressions are gender, age, time since graduation, time since graduation squared, country dummies, level of education; (C)-(D) additionally control for mother's education, father's education and number of books at home. Data are weighted using sampling weights and giving same weight to each country. ${ }^{*}\left({ }^{* *}\right)\left(\left({ }^{* *}\right)\right)$ indicates significance at the $10 \%(5 \%)((1 \%))$ significance level. Robust standard errors in parentheses. Source: PIAAC - Authors' calculations. 